\title{
INTERNATIONAL WORKSHOP Desiccation Tolerance and Sensitivity of Seeds and Vegetative Plant Tissues
}

This specialist Workshop is designed for those seed biologists and plant physiologists who are particularly concerned with aspects of desiccation-tolerance and sensitivity.

The Workshop is to be held in the Kruger National Park, South Africa from January 17th to 22nd, 1994 and is being organised by Patricia Berjak and Norman Pammenter (Dept. of Biology, University of Natal, King George V Ave, Durban, 4001 South Africa).

An optional week-long field trip will follow. While participation is restricted in terms of total numbers and field of interest, a few late applications can still be considered, as long as these are received by October 11th.

Applications should be communicated by Email to Berjak @ lourie.und.ac.za or Pammenter @ biology.und.ac.za Fax: +27-31-816 1195/ +27.31.8162029

\section{Special Issue of Seed Science Research}

The June, 1994 issue of the journal will contain papers presented at the International Workshop, Desiccation Tolerance and Sensitivity of Seeds and Vegetative Plant Tissues to be held in January, 1994

Orders for copies of this issue should be sent to:

Lorraine Rogers,

Marketing and Distribution Services,

CAB International,

Wallingford,

Oxon, OX10 8DE

UK

Tel: 0491832111

Fax: 0491826090 


\section{ANNOUNCEMENT}

\section{ISTA/ISHS SYMPOSIUM}

\section{Technological Advances in Variety and Seed Research 31 May - 3 June 1994 Wageningen, The Netherlands}

This symposium is the result of collaboration between ISTA and ISHS and intends to bring together experts on varieties from both organizations - the official seed testers, institutional research personnel, commercial plant breeders and seed technologists. The symposium will focus on new molecular and physical techniques for the development and assessment of varieties and for the determination and enhancement of seed quality.

Sessions on: Genetics (identification, molecular markers, somaclonal variation, gene expression and manipulation)

Physiology (germination, vigour, desiccation, oxidative stress)

Pathology (diagnostics, etiology, epidemiology, resistance)

Technology (NMR, NIR, X-ray, image analysis, etc.)

Enquiries to the symposium secretariats:

For scientific matters:

IR. W. J. van der Burg, DLO-Centre for Plant Breeding and Reproduction Research, Dept of Reproduction Technology, PO Box 16, 6700 AA Wageningen, The Netherlands

Telephone: +318370 $76984 \quad$ Fax: +31837015983

For organizational matters:

Section Organization Course and Conferences, International Agricultural Centre (IAC), PO Box 88, $6700 \mathrm{AB}$ Wageningen, The Netherlands

Telephone: +31837090287 Fax: +31837018552

Contact the above without delay for the preliminary registration form (first circular and call for papers). 


\title{
FIFTH INTERNATIONAL WORKSHOP ON SEEDS
}

\author{
Basic and Applied Aspects of Seed Biology \\ University of Reading, UK
}

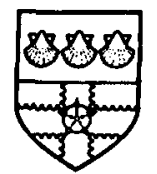

\section{1 - 15 September 1995}

\section{First Circular: Preliminary Registration}

The fifth meeting in the series of International Workshops which began in Israel in 1979 (continuing at Wageningen in 1985, Williamsburg in 1989, Angers in 1992) will be held at the University of Reading, UK, between Monday 11 and Friday 15 September 1995.

Reading lies 40 miles west of London, 30 minutes by train. London's international airports at Heathrow and Gatwick have direct bus and train connections to Reading.

I am pleased to invite you to the meeting. Please complete the form below if you wish to receive the second circular providing details of the meeting and how to book accommodation, etc. Your prompt return of this form to me at the address shown below will enable me to better gauge the demand for accommodation, and also to determine the themes of the scientific programme. Please copy this form to interested colleagues.

I look forward to receiving your reply.

Richard Ellis (1995 Conference),

Department of Agriculture, University of Reading,

Earley Gate, P.O. Box 236,

Reading RG6 2AT, UK

FIFTH INTERNATIONAL WORKSHOP ON SEEDS, READING 1995 Preliminary Registration

NAME (Mr/Ms/Mrs/Dr/Prof)

ADDRESS

I am interested in presenting a paper/poster* on (please give subject area or list keywords)

I would prefer accommodation in a medium-grade hotel (about $\mathfrak{f 7 0}$ per night, including breakfast)/a university hall of residence (from $£ 30$ to $£ 45$ per night, including meals)* *please delete as appropriate 


\title{
Seeds: The Ecology of Regeneration in Plant Communities
}

\author{
Edited by Michael Fenner, Department of Biology, University of \\ Southampton, UK
}

This book provides a comprehensive overview of all aspects of seed ecology. This subject is of major concern to plant ecologists, as in higher plants, natural selection can only have new genetic combinations on which to act through regeneration by seeds (as opposed to vegetative or clonal means). The emphasis of the book is on elucidating the process of regeneration in the field, but laboratory studies have been included where

appropriate. The chapters follow in roughly chronological sequence from seed production on the parent plant through the dispersal, predation, dormancy and seed banks to germination and the establishment of seedlings in the landscape. The book will be invaluable for senior students and research workers in seed science and plant ecology.

\section{Contents}

- Reproductive allocation and reproductive effort in plants F A Bazzaz and D D Ackerly

- Maternal effects on seeds during development Y Gufterman

- The ecology of seed dispersal MF Willson

- Animals as seed dispersers EW Stiles

- Fruits and frugivory P Jordano

- Seed predators and plant population dynamics $M J$ Crawley

- Longevity, viability and dormancy $A J$ Murdoch and $R H$ Ellis

- The functional ecology of seed banks K Thompson

- Seed responses to light $T L$ Pons

- The role of temperature in germination ecophysiology $R J$ Probert

- Effect of chemical environment on seed germination CM Karssen and HWM Hilhorst

- The contribution of seedling regeneration to the structure and dynamics of plant communities and larger units of landscape $J P$ Grime and $S$ H Hillier

May $1992 \quad 370$ pages $\quad$ Hardback ISBN 0851987265

Price: $£ 49.50$ (US\$94.00 Americas only)

\section{$C \cdot A \cdot B$ International}

Headquarters

$C A B$ International Wallingford

Oxon OX10 8DE UK

Tel: (0491) 832111

Telex: 847964 (COMAGG G) Fax: (0491) 833508

For further information please contact:

North America

$C A B$ International 845 North Park Avenue

Tucson, Arizona 85719 USA

Tel: $800 / 528-4841$

602/621-7897

Fax: 602/621-3816
Asia

$C A B$ International

PO Box 11872

50760 Kuala Lumpur Malaysia

Tel: (03) 2552922

Telex: 28031 (MA CABI) Fax: (03) 2551888
Caribbean and Latin America $C A B$ International 10 Gordon Street Curepe

Trinidad E Tobago Tel: 01018096624173

Telex: 029424438 (CARIRI) Fax: 01018096632859 


\section{Seed Science Research}

Invited Review

Hendry, G. A. F. Oxygen free radical processes and seed longevity

Research Papers

Berjak, P., Vertucci, C. W. \& Pammenter, N. W. Effects of developmental status and dehydration rate on characteristics of water and desiccation-sensitivity in recalcitrant seeds of Camellia sinensis

Bino, R. J., Aartse, J. W. \& van der Burg, W. J. Non-destructive X-ray analysis of Arabidopsis embryo mutants

Liu, Y., van der Burg, W. J., Aartse, J. W., van Zwol, H., Jalink, H. \& Bino, R. J. X-ray studies on changes in embryo and endosperm morphology during priming and imbibition of tomato seeds

Livesley, M. A. \& Bray, C. M. Heat shock and recovery in aged wheat aleurone layers

Perez, M. D., Chambers, S. J., Bacon, J. R., Lambert, N., Hedley, C. L. \& Wang, T. L. Seed protein content and composition of near-isogenic and induced mutant pea lines

Thornton, J. M., Collins, A. R.S. \& Powell, A. A. The effect of aerated hydration on DNA synthesis in embryos of Brassica oleracea L.

Vertucci, C. W. \& Roos, E. E. Theoretical basis of protocols for seed storage II. The influence of temperature on optimal moisture levels

Correspondence

Vertucci, C. W. \& Roos, E. G. Seed storage, temperature and relative humidity: Response 